\title{
PENGARUH MOTIVASI KERJA, BUDAYA ORGANISASI DAN PEMBERIAN KOMPENSASI TERHADAP KINERJA KARYAWAN PT NASMOCO BAHANA MOTOR BANTUL YOGYAKARTA
}

\author{
Faris Munandar \\ Farismunandar550@gmail.com \\ Universitas Ahmad Dahlan \\ Utik Bidayati \\ utikbidayati@yahoo.com \\ Universitas Ahmad Dahlan
}

\begin{abstract}
ABSTRAK
This study aims to determine the effect of Employee Engagement, Organizational Commitment, and Transformational Leadership on Readiness for Change in employees of Ahmad Dahlan University, Yogyakarta. The population in this study were 357 employees of Ahmad Dahlan Yogyakarta University and the sample used was 103 people, the sampling technique used was purposive sampling with sample criteria were permanent employees with a minimum working period of one year and had not moved to campus 4 UAD. The data analysis tool used is multiple linear regression test. The results of this study indicate that Employee Engagement has no effect on Readiness for Change at Ahmad Dahlan University employees. Organizational Commitment affects the Readiness for Change of Ahmad Dahlan University employees. Transformational Leadership has no effect on Readiness for Change at Ahmad Dahlan University employees. And employee engagement, organizational commitment, and transformational leadership simultaneously influence the readiness for change in employees of Ahmad Dahlan University, Yogyakarta.
\end{abstract}

Keyword: Employee engagement, organizational commitment, influential transformational leadership, readiness for change.

\section{PENDAHULUAN}

Setiap organisasi dalam menanggapi arus globalisasi sumber daya manusia (SDM) memegang peranan yang sangat dominan dalam aktivitas atau kegiatan perusahaan. Berhasil atau tidaknya perusahaan dalam mencapai tujuan yang ditetapkan sebelumnya sangat tergantung pada kemampuan sumber daya manusiany dalam menjalankan tugas-tugas yang diberikan kepadanya. selain itu karyawan merupakan aset yang sangat bernilai bagi perusahaan. kelangsungan hidup suatu organisasi salah satunya tergantungnya kepada kinerja karyawan dalam melaksanakan pekerjaan karena karyawan merupakan unsur organisasi terpenting yang harus mendapat perhatian. Pencapaian tujuan organisasi menjadi kurang efektif apabila banyak karyawannya yang tidak memiliki kinerja yang baik dan hal ini akan menimbulkan pemborosan bagi perusahaan atau organisasi. Oleh karena adanya manajemen SDM sangat diperlukan yang mana arti dari manajemen sumber daya manusia itu sendiri adalah ilmu dan seni mengatur hubungan dan peranan tenaga kerja efektif dan efisien membantu terwujudnya tujuan perusahaan, karyawan dan masyarakat. Unsur manajemen sumber daya manusia adalah manusia yang merupakan tenaga kerja pada perusahaan (Hasibuan,2009). Dalam meningkatkan sumber daya manusia khususnya kinerja 
karyawan, perusahaan menempuh beberapa cara misalnya melalui pendidikan, pelatihan, permberian kompensasi yang layak, menciptakan lingkungan kerja yang kondusif dan pemberian motivasi. Dalam hal ini motivasi sangat penting karena motivasi adalah proses mempengaruhi ataumendorong dari luar terhadap kelompok kerja agar mereka mau melaksanakan sesuatu yang telah di tetapkan (Samsudin, 2006). Melalui proses-proses tersebut, karyawan diharapkan lebih memaksimalkan tanggung jawab atas pekerjaan mereka karena para karyawan telah terbekali oleh pendidikan dan pelatihan yang tentu berkaitan dengan implementasi kerja mereka. Salah satu motivasi yang dapat diberikan perusahaan adalah dengan pemberian kompensasi. Pemberian kompensasi pada dasarnya adalah hak para karyawan dan merupakan kewajiban dari pihak perusahaan untuk mendukung konstribusi para karyawannya dalam rangka mencapai mencapai tujuan yang telah ditentukan.

Tidak hanya faktor motivasi saja yang perlu diperhatikan oleh perusahaan guna meningkatkan kinerja karyawan, akan tetapi perusahaan harus memperhatikan faktor budaya organisasi.

Budaya organisasi dipercaya sebagai perekat dalam organisasi yang mengalami perubahan. Membangun budaya organisasi tentu tidak semudah mengucapkannya, harus melalui suatu proses lama dan berkelanjutan. Disebut berkelanjutan karena nilai-nilai dan norma-norma yang terkandung dalam budaya tersebut terus menerus mengalami perubahan dan berkembang sesuai dengan zamannya. Oleh karena itu budaya organisasi perlu dibangun sedemikian rupa agar fleksibel, adaptif dan akomodatif terhadap aneka perubahan sehingga cita-cita organisasi yang memiliki keunggulan bukan sekedar impian. Organisasi dengan budaya tertentu memberikan daya tarik bagi individu dengan karakteristik tertentu untuk bergabung. Budaya organisasi bersifat nonformal atau tidak tertulis namun mempunyai peranan penting sebagai cara berpikir, menerima keadaan dan merasakan sesuatu dalam perusahaan tersebut. Pada akhirnya, apabila suatu organisasi atau perusahaan dapat menerapkan dan mengembangkan budaya yang teopat dan baik, maka dapat meningkatkan kinerja karyawan sekaligus memudahkan dalam mencapai tujuan organisasi.

Kompensasi menurut Hasibuan (2002) adalah semua pendapatan yang berbentuk uang, barang langsung atau tidak langsung yang diterima karyawan sebagai imbalan atas jasa yang diberikan kepada karyawan. Tujuan pemberian kompensasi antara lain adalah sebagai ikatan kerjasama, kepuasan kerja, pengadaan efektif, motivasi, stabilitas karyawan, disiplin, serta pengaruh serikat buruh dan pemerintah.

Motivasi, budaya organisasi dan kompensasi yang baik tentu saja akan meningkatkan kinerja para karyawan. Kinerja karyawan merupakan suatu hal yang sangat penting dalam usaha organisasi untuk mencapai tujuan. Jika program tersebut dirasakan adil dan kompetitif oleh karyawan, maka perusahaan akan lebih mudah untuk menarik karyawan yang potensial, sehingga produktivitas meningkat dan perusahaan mampu menghasilkan produk dengan harga yang kompetitif. Berdasarkan uraian diatas dapat dilihat 4 bahwa pemberian kompensasi dan motivasi dapat meningkatkan kinerja karyawan pada sebuah perusahaan.

\section{Rumusan Masalah}

1. Apakah ada pengaruh antara motivasi kerja terhadap kinerja karyawan PT Nasmoco Bahana Motor Bantul?

2. Apakah ada pengaruh antara budaya organisasi terhadap kinerja karyawan PT Nasmoco Bahana Motor Bantul?

3. Apakah ada pengaruh antara pemberian kompensasi terhadap 
kinerja karyawan PT Nasmoco Bahana Motor Bantul?

4. Apakah ada pengaruh antara motivasi kerja, Budaya Organisasi dan pemberian Kompensasi secara simultan terhadap Kinerja karyawan PT Nasmoco Bahana Motor Bantul?

\section{REVIEW LITERATUR DAN HIPOTESIS}

\section{Landasan Teori}

\section{Pengertian Motivasi}

Motivasi diartikan sebagai faktorfaktor yang mengarahkan dan mendorong perilaku atau keinginan seseorang untuk melakukan suatu kegiatan yang dinyatakan dalam bentuk usaha yang keras atau lemah (Hariandja,2002). Motivasi adalah proses mempengaruhi atau mendorong dari luar terhadap atau kelompok kerja agar mereka mau melaksanakan sesuatu yang telah ditetapkan (Samsudin,2006). Motivasi juga diartikan sebagai proses yang menjelaskan intensitas, arah, dan ketekunan seorang individu untuk mencapai suatu tujuannya (Robbin dan Timhoty,2008).

\section{Teori Motivasi.}

Berikut ini berbagai teori motivasi menurut para pakarnya yaitu Teori Motivasi Kebutuhan Maslow, Teori Motivasi Herzberg (1966), Teori motivasi Douglas McGregor, Teori Motivasi Vroom (1964), Achievement theory Mc Clelland (1961), Clayton Alderfer ERG. Dalam penelitian ini teori motivasi yang dipergunakan adalah teori motivasi Mcclelland.

\section{Budaya Organisasi}

Budaya Organisasi adalah kumpulan nilai-nilai dan norma yang mengendalikan interaksi antara anggota organisasi dengan anggota lainnya dan dengan orang yang berada di luar organisasi.(Jones,2001). (Schein,1992). Dalam definisi ini Schein menegaskan bahwa budaya adalah pola asumsi dasar dimana kelompok mempelajari untuk memecahkan masalah adaptasi eksternal dan integrasi internal yang telah berhasil dengan baik sehingga dianggap sah untuk diajarkan kepada para anggota baru sebagai cara yang tepat untuk berfikir,melihat, merasakan dan memecahkan suatu masalah.

\section{Kompensasi}

a. Pengertian kompensasi

Pada dasarnya manusia bekerja juga ingin memperoleh uang untuk memenuhi kebutuhan hidupnya. Untuk itulah seorang karyawan mulai menghargai kerja keras dan semakin menunjukan loyalitas terhadap perusahaan dan karena itulah perusahaan memberikan penghargaan terhadap prestasi kerja karyawan yaitu dengan jalan memberikan kompensasi. Salah satu cara manajemen untuk meningkatkan kinerja para karyawan adalah melalui kompensasi (mathis dan Jackson, 2000).

Kompensasi merupakan istilah luas yang berkaitan dengan imbalanimbalan finansial yang diterima oleh orang-orang melalui hubungan kepegawaian mereka dengan organisasi (Siswanto,2003).

\section{b. Kompensasi Intrinsik}

Kompensasi intrinsik adalah kompensasi yang dinilai di dalam dan dari mereka sendiri. Kompensasi intrinsik bersifat internal bagi individu dan normalnya berasal dari keterlibatan dalam aktivitas-aktivitas atau tugas tertentu. Kompensasi intrinsik melekat/inheren pada aktivitas itu sendiri,dan pemberiannya tidak tergantung pada kehadiran atau tindakan orang lain atau hal lainnya (Henry Simamora, 2004).

\section{Kinerja}

a. Pengertian Kinerja

Kinerja adalah apa yang dilakukan atau tidak dilakukan karyawan (Mathis dan Jackson,2002). Kinerja adalah hasil kerja secara kualitas dan kuantitas yang dicapai oleh seorang karyawan dalam melaksanakan tugasnya sesuai dengan 
tanggung jawab yang diberikannya (Mangkunegara 2004).

Kinerja dapat diartikan sebagai apa yang dikerjakan atau tidak dikerjakan oleh seseorang karyawan dalam melaksanakan tugas-tugas pokoknya (Namawi 2006).

\section{b. Meningkatkan Kinerja}

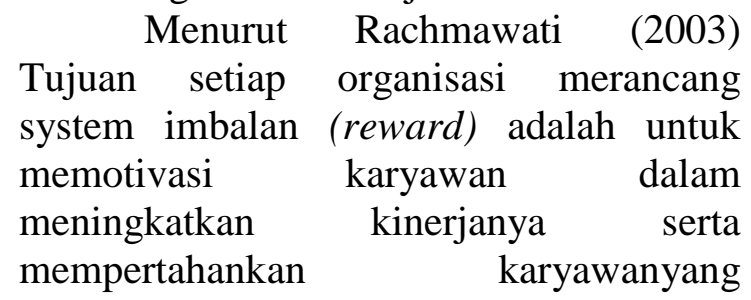
kompeten. Dengan merancang sistem imbalan yang baik akan memiliki dampak ganda bagi organisasi, karena disatu sisi imbalan akan berdampak pada biaya operasi, disisi lain imbalan akan mempengaruhi perilaku serta sikap kerja karyawan sesuai keinginan organisasi agar karyawan dapat meningkatkan kinerjanya. Hal ini dapat dipahami karena salah satu tujuan seseorang bekerja mengharapkan imbalan dari organisasi dimana ia bekerja, sedangkan pihak perusahaan mengharapkan karyawan memberikan kinerja yang terbaik bagi organisasi.

\section{Penelitian Terdahulu}

1. Wijonarko (2012) Melakukan penelitian tentang Pengaruh Budaya Organisasi dan Motivasi terhadap Kinerja Pegawai Negeri Sipil Dinas Pertanian Provinsi DIY.Berdasarkan penelitian yang telah dilakukan dan dilanjutkan dengan menganalisa data maka terdapat pengaruh signifikan antara Budaya Organisasi terhadap kinerja pegawai.dlihat dari nilai signifikansi lebih kecil dari alpha $(0,002<0,05)$ serta terdapat juga pengaruh motivasi terhadap kinerja pegawai dilihat dari nilai signifikansi lebih kecil dari nilai alpha $(0,000<0,05)$.

2. Fajar Kurnadi (2012) Menyatakan penelitian dengan judul pengaruh kompensasi dan motivasi terhadap kinerja karyawan apotek berkah bandung. Penelitian ini menunjukan mengenai pemberian kompensasi yang diberikan apotek berkah dinilai baik, karena nila rata-rata keseluruhan pernyataan adalah sebesar 4,06 berada pada interval 3,40-4,19.

3. Fauzan Hanif (2014) menyatakan penelitian dengan judul pengaruh motivasi kerja dan pemberian kompensasi terhadap kinerja karyawan PT radio permata Swaranusa. Penelitian ini menunjukan mengenai Hasil analisis yang telah dilakukan menghasilkan bahwa motivasi berpangaruh signifikan thitung 2,561 > t-tabel 2,052 sedangkan kompensasi tidak signifikan t-hitung $215<\mathrm{t}$-tabel 2,052 dan secara bersama-sama (simultan) variabel independennya (pengaruh motivasi kerja dan pemberian kompensasi) berpengaruh secara signifikan terhadap variabel dependen (kinerja karyawan) karena $\mathrm{f}$ hitung 3,491 > f tabel 3,35 maka hipotesis diterima.

\section{Hipotesis}

H1: Ada pengaruh motivasi kerja terhadap kinerja karyawan.

$\mathrm{H} 2$ : Ada pengaruh budaya organisasi terhadap kinerja karyawan.

H3: Ada pengaruh pemberian kompensasi terhadap kinerja karyawan.

H4: Ada pengaruh motivasi kerja, budaya organisasi dan pemberian kompensasi secara simultan terhadap kinerja karyawan.

\footnotetext{
METODE PENELITIAN

\section{Populasi dan Sampel}

Populasi adalah wilayah generalisasi yang terdiri atas obyek yang mempunyai kualitas dan karakteristik tertentu yang diterapkan oleh peneliti untuk dipelajari dan kemusian ditarik kesimpulannya (Sugiono, 2008). Populasi dalam penelitian ini adalah seluruh
} 
karyawan Nasmoco Bantul Yogyakarta 200 karyawan.

Sampel adalah bagian dari jumlah dan karakteristik yang dimiliki oleh populasi tersebut (Sugiono, 2008). Dalam penelitian menggunakan sampling purposive yaitu teknik penentuan sampel berdasarkan pertimbangan tertentu. Sugiyono (2013).

\section{Definisi Operasional}

Kuesioner untuk variabel penelitian diambil dri kuesioner yang sudah dipergunakan oleh: Yunus Wijonarko (2012) tentang Budaya Organisasi dan Kinerja Karyawan, Fauzan Hanif (2014) tentang Motivasi kerja dan Desi Apriyani (2013) tentang kompensasi.

\section{Variabel Independen}

Motivasi Kerja

(Variabel

\section{Independent) X1}

Motivasi diartikan sebagai faktor faktor yang mengarahkan dan mendorong perilaku atau keinginan seseorang untuk melakukan suatu kegiatan yang dinyatakan dalam bentuk usaha yang keras atau lemas (Hariandja, 2002). Motivasi kerja adalah sesuatu yang menimbulkan semangat atau dorongan kerja (As'ad,2004). Pada penelitian ini yang digunakan peneliti adalah teori motivasi oleh McClelland (Sule dan Saefullah, 2008) yang meliputi kebutuhan untuk berprestasi, afiliasi dan kebutuhan akan kekuasaan.

\section{Budaya Organisasi (Variabel Independent) X2}

Budaya Organisasi adalah suatu pola asumsi dasar yang di ciptakan, ditemukan atau dikembangkan oleh kelompok tertentu sebagai pembelajaran untuk mengatasi masalah adaptasi eksternal dan integrasi internal yang resmi dan terlaksana dengan baik dan oleh karena itu diajarkan / diwariskan kepada anggota-anggota baru sebagai cara yang tepat untuk memahami, memikirkan, dan merasakan terkait dengan masalah tersebut (Schein dalam Tika, 2006).

\section{Kompensasi independent) $\mathrm{X3}$}

(Variabel

Kompensasi merupakan istilah luas yang berkaitan dengan imbalanimbalan finansial yang diterima oleh orang-orang melalui hubungan kepegawaian mereka dengan organisasi (Siswanto,2003). Macam-macam kompensasi yang diberikan pada karyawan. Jenis kompensasi yang diteliti adalah imbalaan ekstrinsik. imbalan ekstrinsik yang berbentuk uang antara lain misalnya: Gaji, upah, honor, bonus, komisi, insentif, dll. Imbalan ekstrinsik yang bentuknya sebagai benefit / tunjangan pelengkap contohnya seperti: uang cuti, uang makan, uang transportasi / antar jemput, asuransi, jamsostek / jaminan sosial, tenaga kerja, uang pensiun, rekreasi, beasiswa melanjutkan kuliah, dsb.

\section{Variabel Dependen}

Kinerja karyawan (variabel dependent) $\mathbf{Y}$

Kinerja adalah hasil kerja secara kualitas dan kuantitas yang dicapai oleh seorang karyawan dalam melaksanakan tugasnya dengan tanggung jawab yang diberikannya (Mangkunegara 2004). Kinerja dapat diartikan sebagai apa yang dikerjakan atau tidak dikerjakan oleh seseorang karyawan dalam melaksanakan tugas-tugas pokoknya (Nawawi 2006).

\section{Uji Instrumen}

Uji kualitas instrumen dilakukan untuk mengetahui validitas dan reliabilitas dari instrumen penelitian. Uji kualitas instrumen dilakukan dengan bantuan alat uji SPSS V.20. Dalam penelitian ini 
dilakukan uji kualitas instrumen yang terdiri dari uji validitas dan reabilitas.

1. Uji Validitas

Uji validitas merupakan derajat ketepatan antara data yang terjadi pada obyek penelitian dengan data yang dapat dilaporkan peneliti. Dengan demikian data yang valid adalah data yang tidak berbeda antara yang dilaporkan oleh peneliti dengan sesungguhnya terjadi pada obyek peneliti. Bila peneliti membuat laporan yang tidak sesuai dengan apa yang terjadi pada obyek, maka data tersebut dapat dinyatakan tidak valid (sugiono,2008).

Adapun langkah-langkah sebagai berikut:

1) Menentukan kaidah pengambilan keputusan jika $r$ hitung positif dan $r$ hitung > $r$ tabel maka data tersebut valid, sedangkan jika $r$ hitung tidak positif dan $r$ hitung $<r$ tabel maka data tersebut tidak valid.

2) Membandingkan $r$ hitung dengan $r$ tabel tingkat signifikansi 5\% dengan $\mathrm{df}=$ jumlah kasus -2

3) Membuat kesimpulan.

2. Uji Reliabilitas

Reliabilitas berkenan dengan derajat konsistensi dan stabilitas data atau temuan. Dalam pandangan kuantitatif, suatu data dinyatakan realiabel apabila dua atau lebih peneliti dalam obyek yang sama dalam waktu berbeda menghasilkan data yang sama, atau sekelompok data bila dipecah menjadi dua menunjukan data yang tidak berbeda (Sugiono, 2008). dengan alpha 0.05. untuk menguji realiabilitas dalam pengujian ini adalah dengan membandingkan cronbach alpha pada hasil olahan SPSS V.20 dengan rule of thumb dari kesepakatan umu koefisien alpha yaitu lebih besar dari 0.05 .

\section{Teknik Analisis Data}

Untuk menganalisa data yang dikumpulkan dalam penelitian, maka tahap selanjutnya adalah rancangan analisis data. Dalam pengelolahan data ini, peneliti menggunakan dua cara :

a. Metode Deskriptif

Metode yang digunakan untuk menganalisis data dengan cara mendiskripsikan atau menggambarkan data yang telah terkumpul sebagaimana adanya tanpa bermaksud membuat kesimpulan yang berlaku untuk umum atau generalisasi.

b. Metode Kuantitatif

Yaitu metode yang digunakan untuk menganalisisi data atau keterangan yang berbentuk angka-angka guna menarik suatu kesimpulan data dengan metode analisis statistik sebagai berikut : menghubungkan dua variabel atau lebih untuk mengetahui besarnya pengaruh dari perubahan variabel bebas terhadap variabel terikat dan dengan bantuan program SPSS V.20 for windows 18. Dengan menggunakan analisis regresi linier berganda dapat diketahui pengaruh variabel independent motivasi kerja (X1), Budaya Organisasi (X2), pemberian kompensasi (X3) terhadap variabel dependent yaitu kinerja karyawan (Y).

Adapun rumus untuk menghitung regresi linier berganda adalah sebagai berikut: $Y=a+b 1 X 1+b 2 X 2+b 3 X 3+e$ Dimana:

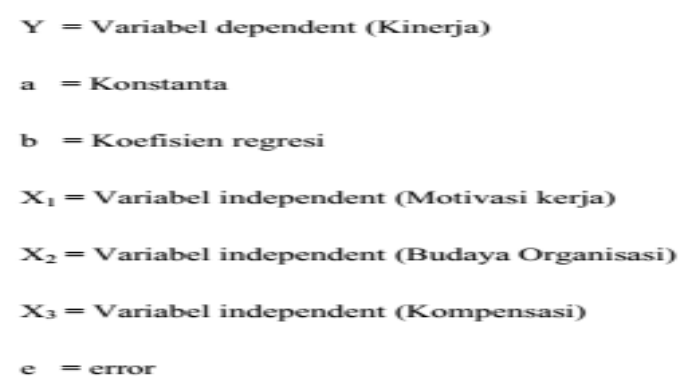

1. Uji Parsial (Uji T)

Ujit digunakan untuk mengetahui signifikansi pengaruh variabel independent secara individu terhadap variabel dependent untuk menyatakan menolak atau menerima hipotesis. Langkah Ujit statistic sebagai berikut : 
a. Perumusan hipotesis pertama

H0: Tidak ada pengaruh signifikan anatara motivasi kerja terhadap kinerja karyawan.

H1: Ada pengaruh signifikan antara motivasi kerja terhadap kinerja karyawan.

b. Perumusan hiptesis ke-dua

H0: Tidak ada pengaruh signifikan antara budaya organisasi terhadap kinerja karyawan

$\mathrm{H} 2$ : Ada pengaruh signifikan antara budaya organisasi terhadap kinerja karyawan.

c. Perumusan hipotesis ke-tiga

H0: Tidak ada pengaruh signifikan antara kompensasi terhadap kinerja karyawan

H3: Ada pengaruh signifikan antara kompensasi terhadap kinerja karyawan.

d. Penentuan nilai kritis. Menggunakan tingkat kepercayaan 95\% dengan tingkat signifikansi $(\alpha$ : $0.05)$ dan $\mathrm{df}=(\mathrm{n}-\mathrm{k})$.

1. Jika $t$ hitung $>\mathrm{t}$ tabel maka, Ho ditolak dan Ha diterima.

Jika t hitung < t tabel maka, Ho diterima dan Ha ditolak.

2. Pengambilan keputusan.

\section{Uji Simultan (Uji F)}

Uji $F$ ini digunakan untuk menghitung signifikansi pengaruh variabel independent secara bersamasama terhadap variabel dependent. Langkahlangkah Uji F statistik sebagai berikut:

a) Perumusan hipotesis

H0: Tidak ada pengaruh signifikan antara motivasi, budaya organisasi dan pemberian kompensasi secara simultan terhadap kinerja karyawan.

H1: Ada pengaruh yang signifikan antara motivasi kerja, budaya organisasi dan kompensasi secara simultan terhadap kinerja karyawan.

b) Jika F hitung > F tabel maka, Ho ditolak dan Ha diterima.

Jika $\mathrm{F}$ hitung $<\mathrm{F}$ tabel maka, Ho diterima dan Ha ditolak

c) Menarik kesimpulan.

\section{HASIL PENELITIAN DAN PEMBAHASAN}

\section{Analisi Deskriptif}

Untuk mendapatkan data dari responden peneliti menyebarkan kuesioner di PT Nasmoco Bahana Motor Bantul Yogyakarta, setelah itu penelitian pun dilakukan dengan menyebarkan kuesioner kepada objek penelitian.

Berikut ini peneliti telah menganalisis data yang telah terkumpul. Data yang digunakan merupakan hasil jawaban dari para responden yaitu Karyawan tetap PT Nasmoco Bahana Motor Bantul Yogyakarta. Hasil dari pengolahan data adalah informasi untuk mengetahui apakah kinerja kerja pada PT Nasmoco Bahana Motor Bantul Yogyakarta dipengaruhi oleh motivasi, budaya organisasi dan pemberian kompensasi. Kuesioner yang telah disebarkan sebanyak 103 buah kemudian diolah kedalam SPSS 20. Dalam penelitian ini terdapat karakteristik responden yang diklasifikasikan berdasarkan usia, jenis kelamin dan pendidikan.

Adapun data karakteristik responden tersebut sebagai berikut :

\begin{tabular}{|c|c|c|c|}
\hline \multicolumn{4}{|c|}{ Usia Responden } \\
\hline NO. & Usia & Jumlah & Prosentase \\
\hline 1 & 20-30 Tahun & 81 & $78.64 \%$ \\
\hline 2 & 31-40 Tahun & 19 & $18.44 \%$ \\
\hline 3 & 41-50 Tahun & 3 & $2.91 \%$ \\
\hline & Total & 103 & $100 \%$ \\
\hline
\end{tabular}

Dari tabel diatas dapat diketahui bahwa usia karyawan yang paling banyak adalah berusia 20-30 Tahun yang berjumlah 81 karyawan, dan 19 karyawan yang berusia 31-40 Tahun, dan 3 
karyawan yang berusia 41-50 Tahun.

Tabel 5.2

Jenis kelamin Responden

\begin{tabular}{|c|c|c|c|}
\hline NO & Jenis Kelamin & Jumlah & Prosentase \\
\hline 1 & Laki-Laki & 85 & $82.52 \%$ \\
\hline 2 & Perempuan & 18 & $17.47 \%$ \\
\hline \multicolumn{2}{|c|}{ Total } & 103 & $100 \%$ \\
\hline \multicolumn{2}{|c|}{ Sumber: Data Primer kuesioner diolah (2015) }
\end{tabular}

Dari tabel diatas, dapat diketahui bahwa mayoritas karyawan nasmoco yang berjenis kelamin laki laki yaitu sebanyak 85 atau $82.52 \%$, dan perempuan sebanyak 18 atau $17.47 \%$. Jadi dapat disimpulkan karyawan yang bekerja di Nasmoco Bahana Motor Bantul Yogyakarta lebih banyak yang berjenis kelamin laki-laki dari pada perempuan.

\begin{tabular}{|c|c|c|c|}
\hline NO & Pendidikan & Jumlah & Prosentase \\
\hline 1 & SMU(Sederajat) & 27 & $26.21 \%$ \\
\hline 2 & D3 & 58 & $56.31 \%$ \\
\hline 3 & S1 & 18 & $17.47 \%$ \\
\hline & Total & 103 & $100 \%$ \\
\hline
\end{tabular}

Dari data diatas dapat disimpulkan bahwa karyawan nasmoco bahana motor yogyakarta sebagian besar lulusan D3 yaitu mberjumlah 58 karyawan, Sedangkan lulusan SMU (sederajat) berjumlah 27 karyawan, dan lulusan S1 berjumlah 18 karyawan.

\section{Hasil Penelitian}

1. Hasil Uji Validitas

Uji Validitas digunakan untuk mengukur sah atau valid tidaknya suatu kuesioner. Yaitu dengan membandingkan nilai rhitung dengan $r$ tabel. Adapun hasil perhitungan yang didapat dengan menggunakan program SPSS Versi 20 pada tabel sebagai berikut.
Tabel 5.4

\begin{tabular}{|c|c|c|c|}
\multicolumn{5}{|c|}{ Variabel Motivasi (X1) } \\
\hline NO & r hitung & r tabel & Ket \\
\hline 1 & $0.794^{* *}$ & 0.361 & Valid \\
\hline 2 & $0.709^{* *}$ & 0.361 & Valid \\
\hline 3 & $0.487^{* *}$ & 0.361 & Valid \\
\hline 4 & $0.541^{* *}$ & 0.361 & Valid \\
\hline 5 & $0.532^{* *}$ & 0.361 & Valid \\
\hline 6 & $0.450^{*}$ & 0.361 & Valid \\
\hline 7 & $0.719^{* *}$ & 0.361 & Valid \\
\hline 8 & $0.755^{* *}$ & 0.361 & Valid \\
\hline 9 & $0.523^{* *}$ & 0.361 & \\
\hline
\end{tabular}

1 abel 5.J.

Variabel Budaya Organisasi (X2)

\begin{tabular}{|c|c|c|c|}
\hline NO & r hitung & r tabel & Ket \\
\hline 1 & $0.825^{* *}$ & 0.361 & Valid \\
\hline 2 & $0.848^{* *}$ & 0.361 & Valid \\
\hline 3 & $0.880^{* *}$ & 0.361 & Valid \\
\hline 4 & $0.886^{* *}$ & 0.361 & Valid \\
\hline 5 & $0.828^{* *}$ & 0.361 & Valid \\
\hline 6 & $0.831^{* *}$ & 0.361 & Valid \\
\hline 7 & $0.845^{* *}$ & 0.361 & Valid \\
\hline
\end{tabular}
Tabel 5.6.

\begin{tabular}{|c|c|c|c|}
\hline \multicolumn{5}{|c|}{ Variabel Kompensasi (X3) } \\
\hline NO & r hitung & r tabel & Ket \\
\hline 1 & $0.599^{* *}$ & 0.361 & Valid \\
\hline 2 & $0.840^{* *}$ & 0.361 & Valid \\
\hline 3 & $0.877^{* *}$ & 0.361 & Valid \\
\hline 4 & $0.791^{* *}$ & 0.361 & Valid \\
\hline 5 & $0.723^{* *}$ & 0.361 & Valid \\
\hline 6 & $0.732^{* *}$ & 0.361 & Valid \\
\hline 7 & $0.737^{* *}$ & 0.361 & Valid \\
\hline 8 & $0.644^{* *}$ & 0.361 & Valid \\
\hline
\end{tabular}

Sumber: diolah melalui SPSS V.20 (2015)

\begin{tabular}{|c|c|c|c|}
\hline \multicolumn{5}{|c|}{ Variabel Kinerja karyawan (Y) } \\
\hline 1 & $0.581^{* *}$ & r tabel & Ket \\
\hline 2 & $0.809^{* *}$ & 0.361 & Valid \\
\hline 3 & $0.638^{* *}$ & 0.361 & Valid \\
\hline 4 & $0.706^{* *}$ & 0.361 & Valid \\
\hline 5 & $0.662^{* *}$ & 0.361 & Valid \\
\hline 6 & $0.725^{* *}$ & 0.361 & Valid \\
\hline 7 & $0.770^{* *}$ & 0.361 & Valid \\
\hline 8 & $0.603^{* *}$ & 0.361 & Valid \\
\hline 9 & $0.740^{* *}$ & 0.361 & Valid \\
\hline 10 & $0.530^{* *}$ & 0.361 & \\
\hline
\end{tabular}


Dari tabel yang telah di sajikan sebelumnya, maka diketahui hasil uji validitas sebagai berikut: Kinerja memiliki $r$ hitung $>r$ tabel sehingga dinyatakan valid. Selanjutnya variabel motivasi, budaya organisasi dan kompensasi juga dinyatakan valid masing-masing nilai $r$ hitung > $\mathrm{r}$ tabel.

\section{Hasil Uji Reliabilitas}

Uji Reliabilitas dimaksudkan untuk mengukur suatu kuesioner yang merupakan indikator dari variabel. Reliabilitas diukur dengan uji statistic cronbach's alpha (a). Sutau variabel dikatakan reliabel jika memberikan nilai cronbach's alpha $>0.60$. Adapun hasil perhitungan yang didapat dengan menggunakan program SPSS Versi 20 pada tabel sebagai berikut:

\begin{tabular}{|c|c|c|c|}
\multicolumn{5}{|c}{ Hasil Uji Reliabilitas } \\
\hline Variabel & cronbach's alpha & a- batas & Keterangan \\
\hline Motivasi & 0.790 & 0,60 & Reliabel \\
\hline Budaya Organisasi & 0.935 & 0,60 & Reliabel \\
\hline Kompensasi & 0.879 & 0,60 & Reliabel \\
\hline Kinerja karyawan & 0.866 & 0,60 & Reliabel \\
\hline \multicolumn{2}{|c|}{ Sumber: diolah melalui SPSS V.20 (2015) }
\end{tabular}

Dari Tabel yang telah disajikan sebelumnya, maka diketahui hasil uji reliabilitas dinyatakan reliabel sehingga diketahui masing-masing variabel kinerja dan variabel motivasi memiliki 9 item pernyataan dan cronbach's alpha alpha $>$ a-batas, sehingga dinyatakan reliabel. Selanjutnya variabel budaya organisasi dari data yang telah diolah sebelumnya, memiliki 7 item pernyataan dan hasilnya diketahui cronbach's alpha> a-batas sehingga dinyatakan reliabel dan variabel kompensasi yang memiliki 8 item pernyataan dan hasilnya dinyatakan reliabel.

\section{Hasil Uji Regresi Linier Berganda}

$$
\text { Analisis regresi berganda }
$$
digunakan untuk mengetahui signifikansi pengaruh variabel motivasi, budaya organisasi dan kompensasi terhadap kinerja karyawan PT Nasmoco
Bahana Motor Bantul Yogyakarta. Maka dilakukan pengolahan data melalui persamaan linear berganda dengan menggunakan bantuan program SPSS V.20. Oleh karena itu, hasil dari pengolahan data tersebut, dirangkum dalam tabel tersebut:

$$
\begin{gathered}
\text { Tabel 5.9. } \\
\text { Hasil Analisis Regresi Berganda }
\end{gathered}
$$

Coefficients

\begin{tabular}{|c|c|c|c|}
\hline Variabel & Koefisien Regresi & t hitung & sig \\
\hline X1 & 0.096 & 0.744 & 0.459 \\
\hline X2 & 0.267 & 2.249 & 0.027 \\
\hline X3 & 0.195 & 2.246 & 0.027 \\
\hline konstan & 2.015 & 4.138 & 0.000 \\
\hline \multicolumn{3}{|c|}{ F hitung $=8.068$} \\
Sumber: diolah melalui SPSS V.20 (2015) \\
\hline \multicolumn{3}{|c}{}
\end{tabular}

Dari tabel 4.9. yang telah disajikan sebelumnya, maka hasil yang dapat diperoleh dimasukan kedalam persamaan regresi sebagai berikut:

$\mathrm{Y}=\mathrm{a}+\mathrm{b} 1 \mathrm{X} 1+\mathrm{b} 2 \mathrm{X} 2+\mathrm{b} 3 \mathrm{X} 3+\mathrm{e}$

Diketahui: $\mathrm{Y}=2.015+0.096 \mathrm{X} 1+0.267 \mathrm{X} 2$ $+0.195 \mathrm{X} 3$

\section{Hasil Uji Parsial (Uji T)}

Hasil olah data menunjukkan bahwa ada pengaruh signifikan antara motivasi terhadap kinerja karyawan. Ditunjukkan dengan Nilai $\mathrm{t}$ hitung $<\mathrm{t}$ tabel $(0.744<1.983)$ maka Ho diterima dan Ha ditolak, artinya secara parsial motivasi tidak berpengaruh terhadap kinerja secara signifikan

Hasil olah data menunjukkan bahwa ada pengaruh signifikan antara budaya organisasi terhadap kinerja karyawan. Ditunjukkan dengan Nilai t hitung > t tabel $(2.249>1.983)$ maka Ho ditolak dan Ha diterima, artinya secara parsial budaya organisasi berpengaruh terhadap kinerja secara signifikan. 
Hasil olah data menunjukkan bahwa ada pengaruh signifikan antara budaya organisasi terhadap kinerja karyawan. Ditunjukkan dengan Nilai $t$ hitung > t tabel $(2.246>1.983)$ maka Ho ditolak dan Ha diterima, artinya secara parsial kompensasi berpengaruh terhadap kinerja secara signifikan.

5. Hasil Uji Simultan (Uji F)

Tabel 5.10

\begin{tabular}{|c|c|}
\multicolumn{2}{c}{ Hasil Analisis Uji F } \\
\hline $\mathrm{F}$ & sig \\
\hline 8.068 & 0.000 \\
\hline
\end{tabular}

Sumber: diolah melalui SPSS V.20 (2015)

Hasil uji simultan menunjukkan bahwa ada pengaruh signifikan antara variabel motivasi, budaya organisasi dan kompensasi terhadap kinerja karyawan secara bersama - sama. Ditunjukkan dengan nila $\mathrm{F}$ hitung $>\mathrm{F}$ tabel $(8.068>3.09)$. maka Ho ditolak dan $\mathrm{Ha}$ diterima. Artinya, terdapat pengaruh signifikan antara variabel motivasi, budaya dan kompensasi terhadap kinerja karyawan secara simultan.

6. Hasil Uji Koefisien Determinasi

\begin{tabular}{|c|c|c|c|}
\hline \multicolumn{4}{|c|}{ Model summary ${ }^{\mathrm{b}}$} \\
\hline Model & $\mathrm{R}$ & R Square & $\begin{array}{c}\text { Adjusted R } \\
\text { Square }\end{array}$ \\
\hline 1 & $.443^{\mathrm{a}}$ & .196 & .172 \\
\hline
\end{tabular}

Berdasarkan table 5.11 uji determinasi menunjukan hasil analisis nilai $\mathrm{R}$ square sebagai koefisien determinasi sebesar 0.196 hal ini diartikan bahwa variabel bebas yaitu motivasi,budaya organisasi dan kompensasi secara bersama-sama menjelaskan variabel kinerja karyawan sebesar $19.6 \%$ sedangkan sisanya $81.4 \%$ dijelaskan oleh variabel lain yang tidak diteliti oleh penelitian ini atau model penelitian lain.

\section{Pembahasan}

Berdasarkan teori dan alat analisis data yang digunakan dalam penelitian ini dari hasil uji t menunjukan bahwa variabel budaya organisasi dan kompensasi berpengaruh terhadap kinerja karyawan sedangkan variabel motivasi tidak berpengaruh sehingga dari ke 3 variabel yang tidak berpengaruh adalah variabel motivasi yang artinya motivasi secara internal yang diberikan perusahaan tetapi sebatas memberikan motivasi tidak adanya pantauan dari motivator tesebut. ketika motivasi tidak ada dalam diri karyawan, Maka akan mempengaruhi pola kerja karyawan Sehingga kinerja karyawan kurang maksimal untuk mencapai hasil yang diinginkan perusahaan. Seharusnya motivator selalu memberikan pantauan dalam memotivasi karyawan agar karyawan lebih maksimal dalam bekerja dan menjalankan tugasnya untuk mencapai tujuan.

Selanjutnya hasil dari uji f variabel motivasi, budaya organisasi dan kompensasi berdasarkan hasil analisis regresi linear berganda berpengaruh signifikan terhadap kinerja karyawan karena memiliki nilai koefisien bertanda positif. Maka hipotesis dalam penelitian ini, berdasarkan teori dan alat analisis data uji $\mathrm{t}$ dan uji $\mathrm{F}$ untuk variabel budaya organisasi dan kompensasi terhadap kineja karyawan berpengaruh secara parsial kecuali variabel motivasi. Dan secara simultan keseluruhan signifikan pada PT Nasmoco Bahana Motor bantul Yogyakarta.Dan hasil uji determinasi/R2 menunjukkan variabel X1,X2 \& X3 hanya mampu menjelaskan sebesar $19.6 \%$ terhadap kinerja karyawan pada PT Nasmoco Bahana Motor Bantul Yogyakarta dan sisanya $81.4 \%$ dijelaskan oleh variabel lain yang tidak diteliti oleh penelitian ini. 


\section{KESIMPULAN DAN SARAN}

\section{Kesimpulan}

Berdasarkan hasil penelitian dan pembahasan yang telah disajikan sebelumnya, maka dapat ditarik kesimpulan sebagai berikut :

1. Berdasarkan hasil uji t menunjukkan bahwa variabel Motivasi tidak berpengaruh signifikan terhadap Kinerja karyawan. Ditunjukkan dengan nilai $\mathrm{t}$ hitung $<\mathrm{t}$ tabel $(0.744<1.983)$. Maka Ho diterima dan $\mathrm{Ha}$ ditolak, artinya secara parsial tidak ada pengaruh antara motivasi terhadap kinerja karyawan PT Nasmoco Bahana Motor Bantul Yogyakarta.

2. Berdasarkan hasil uji $\mathrm{t}$ menunjukkan bahwa variabel budaya organisasi berpengaruh signifikan terhadap kinerja karyawan. Ditunjukkan dengan nilai t hitung > t tabel $(2.249>1.983)$. Maka Ho ditolak dan Ha diterima, artinya secara parsial ada pengaruh signifikan antara budaya organisasi terhadap kinerja karyawan PT Nasmoco Bahana Motor Bantul Yogyakarta.

3. Berdasarkan hasil uji t menunjukkan bahwa variabel kompensasi berpengaruh signifikan terhadap kinerja karyawan. Ditunjukkan dengan nilai $\mathrm{t}$ hitung $>\mathrm{t}$ tabel $(2.246>1.983)$. Maka Ho ditolak dan Ha diterima, artinya secara parsial ada pengaruh signifikan antara kompensasi terhadap kinerja karyawan PT Nasmoco Bahana Motor Bantul Yogyakarta

4. Berdasarkan hasil analisis uji $F$ menunjukkan bahwa terdapat pengaruh signifikan antara variabel motivasi, budaya organisasi dan kompensasi terhadap kinerja karyawan. Ditunjukkan dengan nilai $\mathrm{f}$ htiung $>\mathrm{F}$ tabel (8.068> 3.09). Maka Ho ditolak dan Ha diterima, artinya terdapat pengaruh signifikan antara variabel motivasi, budaya organisasi dan kompensasi terhadap kinerja karyawan
PT Nasmoco Bahana Motor Bantul Yogyakarta.

\section{Saran}

1. PT Nasmoco Bahana Motor Bantul Yogyakarta.

Perusahaan hendaknya memberikan budaya organisasi dan kompensasi yang sesuai dengan yang dibutuhkan karyawan. Agar karyawan bertambah semangat bekerja untuk mencapai tujuan bersama.kemudian kinerja karyawan diukur juga oleh atasan atau rekan kerja.

2. Bagi peneliti selanjutnya

Dalam penelitian ini masih banyak kekurangan, Hendaknya melakukan penelitian dengan variabel - variabel diluar dari variabel yang telah peneliti lakukan,dari analisis diatas pengaruh motivasi tidak signifikan dan diharapkan bagi peneliti selanjutnya untuk memperbanyak instrumen dari variabel diatas tersebut.

\section{DAFTAR PUSTAKA}

Apriyani, Desi. 2013. Pengaruh kompensasi finansial dan non finansial terhadap kinerja karyawan pada PT PLN (persero). Skripsi. Universitas sumatera utara.

As'ad, 2004. Seri Ilmu Sumber Daya Manusia Psikologi Industri. Liberty. Yogyakarta.

Hanif, Fauzan. 2014. Pengaruh motivasi kerja dan pemberian kompensasi terhadap kinerja karyawan PT Radio permata swaranusa.Skripsi. Universitas Ahmad Dahlan. Yogyakarta

Hariandja, M. T. 2002. Manajemen Sumber Daya Manusia. PT Gramedia Widiasarana Indonesia. Jakarta. 
Hasibuan, Malayu. 2009. Manajemen Sumber Daya Manusia. Bumi Aksara, Jakarta.

Kurnadi, Fajar. 2012. Pengaruh kompensasi dan motivasi terhadap kinerja karyawan. Skripsi. Universitas Ahmad Dahlan. Yogyakarta.

Mangkunegara, Prabu Anwar A.A. 2001. Manajemen Sumber Daya Manusia Perusahaan. PT Remaja Rosda Karya. Bandung.

Mathis, Robert L. dan Jacson H John. 2001. Manajemen Sumber Daya Manusia. Salemba Empat. Jakarta.

Nawawi, Hadari. 2006. Evaluasi dan Manajemen Kinerja di Lingkungan Perusahaan dan Industri. Gadjah Mada University Press, Yogyakarta.Panggaben, Mutiara S. 2002. Manajemen Sumber Daya Manusia. Ghallia Indonesia. Jakarta.

Prawirosentono, Suryadi. 1999. Kebijakan kinerja karyawan. Yogyakarta : BPFE.

Robbin, Stephen P., dan Timothy A. Judge. 2008. Perilaku Organisasi edisi keduabelas. Salemba Empat. Jakarta.

Samsudin, 2006 definisi motivasi http://lib.uinmalang.ac.id/thesis/chapter ii/08410051- anggun-nurhabsari.ps<1 agustus 2013>

Sugiono. 2008. Metode Penelitian Kuantitatif, Kualitatif dan R\&D edisi Keempat. Alfabeta. Bandung.

Sule, Ernie Tisnawati dan Kurniawan Saefullah. 2008. Pengantar manajemen, Edisi pertama.cetakan ke-3.jakarta: Prenada Media.
Tuti, A dan Fisla . W .2007, Pengaruh budaya organisasi terhadap kinerja karyawan politeknik negeri padang. Jurnal ekonomi dan bisnis. Volume 2 nomor 1: hal 25-26.

Wibowo. 2011. Budaya Organisasi. Jakarta: Pt Rajagrafindo Persada

Wijonarko, Yunus. 2012. Pengaruh Budaya Organisasi dan Motivasi terhadap Kinerja Pegawai Negeri Sipil Dinas Pertanian Provinsi DIY. Skripsi.Universitas Ahmad Dahlan Yogyakarta 